\title{
Characterizing variations of dissolved organic matter (DOM) properties in Nansi Lake: an important reservoir along the eastern route of China's South-to-North Water Diversion Project
}

Haoyu Ren

Liaocheng University

Xin Yao ( $\nabla$ yaoxin@lcu.edu.cn )

Liaocheng University

Feiyang Ma

Liaocheng University

Tuantuan Fan

Liaocheng University

Huanguang Deng

Liaocheng University

Yinghao Zhang

Liaocheng University

\section{Research Article}

Keywords: Nansi Lake, Dissolved organic matter (DOM), EEM, PARAFAC, variation

Posted Date: February 22nd, 2021

DOl: https://doi.org/10.21203/rs.3.rs-157054/v1

License: (c) (i) This work is licensed under a Creative Commons Attribution 4.0 International License.

Read Full License 


\section{Abstract}

Variations in dissolved organic matter (DOM) quality has far-reaching implications that affect, e.g., aquatic productivity, food web structures, trace element and pollutant transport. In this study, a total of 186 water samples were collected at 62 sites (three points in time within one year) in Nansi Lake. UV-Vis spectra, Synchronous fluorescence (SF) spectra, the excitation-emission matrix and parallel factor analysis (EEM-PARAFAC) were applied to indicate the source and quality of DOM. Water transferring of the eastern route of China's South-to-North Water Diversion Project had a great influence on the water level of Nansi Lake. Results of SF spectra, EEM-PARAFAC and principal component analysis (PCA) suggested that protein-like substances played a more important role in DOM properties in April and July than October. This result is related to a high fluorescence intensity occurred in April ( $F$ max $=0.72 \pm 0.03$ in the upper lake and $1.84 \pm 0.13$ in the lower lake) and July ( $F \max =1.10 \pm 0.05$ in the upper lake and $1.49 \pm 0.04$ in the lower lake), which might be caused by water transferring from other lakes to Nansi Lake, death and decomposition of submerged plants. At the same time, relatively good correlations were found between humic-like substances, DOC and $a_{254}$ in April, July and October, which indicated the important contribution of humic-like substances to Nansi Lake. With the completion of the water diversion, the ratio

of the fluorescence intensity of component to the total fluorescence intensity (\% Fmax) suggested that the proportion of humic-like substances started to increase. And when it came to October, humic-like substances become the main substance in DOM collected from Nansi Lake (\%Fmax $=66.56 \% \pm 0.58 \%$ in the upper lake and $61.98 \% \pm 0.99 \%$ in the lower lake). Moreover, among the two areas in Nansi Lake, the upper lake always had a higher degree of humification ( $H I X=2.23 \pm 0.06,2.38 \pm 0.11$ and $3.10 \pm 0.05$ in April, July and October, respectively) than the lower lake (HIX=1.06 $\pm 0.05,1.68 \pm 0.05$ and $2.62 \pm 0.08$ in April, July and October, respectively), which implied extraneous contaminants might have a more important impact on DOM properties in the upper lake.

\section{Introduction}

Organic matter, especially the dissolved organic matter (DOM), is ubiquitous in natural aquatic systems. Sources of DOM are intricate, which can be mainly generated under influences of terrestrial and anthropogenic substances as well as impacts of autochthonous creatures (Chen and Jaffe, 2014; Carr et al., 2019; Tank et al., 2010). DOM is considered as a medium to further explore the destiny of estrogen, heavy metal, greenhouse gas and so on (Bai et al., 2020; Hur and Lee, 2011; Zhou et al., 2018; Zhou et al., 2019). As a result of heterogeneity and activation of DOM, however, relevant research results are inconsistent even opposite (Xu et al., 2019).

As the starting point of relevant studies, DOM properties have always been the focus of attention (Andrew et al., 2013; Yao et al., 2015). And with the rapid development of economy, lakes play a crucial role in electricity, agriculture, industry and other fields. Dam building and wide scale of water transferring is the most common way to adapt lakes to human needs. Nevertheless, reconstruction of lakes had affected the natural properties and distributions of biological communities, nutrient and heavy metals (Cheimonopoulou et al., 2011; Guo et al., 2020b; Maavara et al., 2020, Zhuang et al., 2019). In this 
context, affected on DOM quality by reconstruction of lakes should be deserved more attention, which could bring far-reaching implications to aquatic productivity, food web structures, trace element and pollutant transport, e.g. (Zhang et al., 2021).

China's South-to-North Water Diversion Project (SNWDP) is a representative project that transferring water with a maximum-scale, which aimed to relieve uneven distributions of freshwater resources which were common in China (Guo et al., 2020a). This huge project was designed as three lines that divert water from different directions to north China. Among the three lines, the eastern route of SNWDP convey water from Yangtze River to Tianjin and Qingdao, along the way, which passed many cities with advanced industry and agriculture (Zhang et al., 2020). The eastern route of SNWDP is a key to ensure the health of millions of people and the functioning of cities in north China. Relevant studies are necessary to investigate how DOM properties change under the influence of large-scale water transferred.

As the largest lake along the eastern route of the SNWTP, Nansi Lake is responsible for water conveyance as well as water storage (Zhang et al., 2020). Water flows naturally from north to south, while the transferring of water beginning, the direction of water flowing changed from south to north. Furthermore, compared with other lakes that along the line of this project, Nansi Lake is peculiar that a dam was built in 1975, which might complicate the ecological environment of Nansi Lake.

In this case, we selected Nansi Lake as the research object in this study. Combining with UV-Vis spectra, Synchronous fluorescence (SF) spectra, the excitation-mission matrix and parallel factor analysis (EEM-

PARAFAC model) and official information issued by the Government of the People's Republic of China, we expect to conduct a comprehensive and in-depth study on DOM properties in complex aquatic environments. And primary purposes in this work are following: (1) to better understand the hydrological effect of the eastern route of the SNWTP on Nansi Lake (2) to investigate DOM properties on a spatial and time scale (3) to debate possible reasons for consequences in this work.

\section{Materials And Methods}

\subsection{Samples and DOM extraction}

A total of 186 water samples were collected at 62 sites in April, July and October 2019, respectively. Because Nansi Lake was divided into the upper lake and the lower lake by the dam, 21 sites set in the upper lake, while 41 sites set in the lower lake (Fig. 1). Samples were filtered with Whatman GF/F filters before measured dissolved organic carbon (DOC) by using a TOC-Vcph analyzer (Japan, Shimadzu), and stored in the dark at $4{ }^{\circ} \mathrm{C}$ for subsequent determination.

\subsection{Spectral measurements}

A UV-Vis spectrophotometer (Shimadzu, UV-2550) was applied to measure UV-Vis absorption spectra from 200 to $800 \mathrm{~nm}$ with intervals at $1 \mathrm{~nm}$, Absorption coefficient at $254 \mathrm{~nm}\left(a_{254}\right)$ was considered as a surrogate for the concentration of DOM (Shin et al., 2016; Liu et al., 2020). And SUVA was the ratio of $a_{254}$ 
to DOC. A Hitachi F-7000 fluorescence spectrometer (Hitachi High Technologies, Tokyo, Japan) was used to measure Synchronous fluorescence (SF) spectra and EEM spectra. The Ex wavelength options are from $200 \mathrm{~nm}$ to $450 \mathrm{~nm}$ with a constant offset $(60 \mathrm{~nm})$ for SF spectra. And the scanning excitation (Ex) and emission (Em) for EEMs were set from $200 \mathrm{~nm}$ to $450 \mathrm{~nm}$ and 250 to $600 \mathrm{~nm}$, respectively (Bai et al., 2017).

\subsection{PARAFAC modelling}

PARAFAC modelling in this study was used to quantitative analyse the fluorescence intensity and content of different substances. It can be conducted by drEEM toolbox of MATLAB (R2018b). And details about PARAFAC modelling can be inquired elsewhere (Shi et al., 2019; Yamashita and Jaffé, 2008).

Fluorescence indices (FI, BIX and HIX) were obtained based on results of EEM-PARAFAC modelling. And more details about fluorescence indices can be found elsewhere (Huguet et al., 2009).

\subsection{Disclosure of official information and classification of land use}

Hydrological information was obtained from Ministry of Water Resources of the People's Republic of China and the Huaihe River Commission of the Ministry of Water Resources, P.R.C, which can be found from the websites www.mwr.gov.cn and www.hrc.gov.cn. And Landsat TM images for 2018 found from the website www.gscloud.cn were used to classify land use types. In this study, there were five types: water $(17 \%)$, woodland ( $9 \%)$, cropland (33\%), bareland (17\%) and urban construction land (24\%). Both cropland and urban construction land are classified as anthropogenic land use.

\subsection{Software}

Matlab R2018b, Origin 2018, Arcmap 10.6, R Studio 1.3.959 software and IBM SPSS Statistics 23 were applied for this study.

\section{Results}

\subsection{Hydrological changes of Nansi Lake}

As a typical temperate monsoon climate zone in the northern hemisphere, the basin in which Nansi Lake located, always has a major precipitation in summer (Fig. 2). Rainfall of this basin in July 2019 was $93.9 \mathrm{~mm}$, which was significantly higher than that in April $(53.1 \mathrm{~mm})$ and October $(37.8 \mathrm{~mm})$ of the same year. In general, precipitation could enhance the pondage of lakes. Nevertheless, the impoundage of Nansi Lake was $16.22 \times 10^{8} \mathrm{~m}^{3}$ in April $\left(9.16 \times 10^{8} \mathrm{~m}^{3}\right.$ for the upper lake and $7.06 \times 10^{8} \mathrm{~m}^{3}$ for the lower lake), $6.14 \times 10^{8} \mathrm{~m}^{3}$ in July $\left(3.00 \times 10^{8} \mathrm{~m}^{3}\right.$ for the upper lake and $3.14 \times 10^{8} \mathrm{~m}^{3}$ for the lower lake), $11.03 \times 10^{8} \mathrm{~m}^{3}$ in October $\left(5.60 \times 10^{8} \mathrm{~m}^{3}\right.$ for the upper lake and $5.43 \times 10^{8} \mathrm{~m}^{3}$ for the lower lake), respectively(Fig. 2). Water storage was lowest in the wettest month, which indicated that the impoundage of Nansi Lake might be controlled by other factors. 
According to the information announced by Ministry of Water Resources of the People's Republic of China, we found that the eastern route of the China's South-to-North Water Diversion Project (SNWDP) played a key role in changes of the impoundage in Nansi Lake. The annual water transfer mission from 2018 to 2019 of Nansi Lake began in December 2018 and ended in June 2019. The amount of water transferred to Nansi Lake was $8.44 \times 10^{8} \mathrm{~m}^{3}$, while the amount of water transferred out of Nansi Lake was $6.70 \times 10^{8} \mathrm{~m}^{3}$. There is no doubt that such a large amount of water diversion could make a distinct impact on the aquatic environment of Nansi Lake.

\subsection{Abundance of DOM in Nansi Lake}

The value of DOC and $a_{254}$ could partly characterise the concentration of DOM. Our results suggested that the spatial distribution both of DOC and $a_{254}$ have a decided change under the different hydrological condition. Most of the high values of DOC and $a_{254}$ appeared on the upper lake in April (Fig. 3a, $d$ and Table 1). The average value of DOC and $a_{254}$ in the upper lake was $6.60 \pm 0.29 \mathrm{mg} \mathrm{L}^{-1}$ and $22.32 \pm 0.75$, while mean values of the two indices in the lower lake were $5.81 \pm 0.22 \mathrm{mg} \mathrm{L}^{-1}$ and $17.92 \pm 0.29$. However, compared with the spatial distribution in April, some obvious differences occurred in July and October. There were some high values of DOC and $a_{254}$ were found in the lower lake (Fig. 3b, c, e and f). Especially in July, the average value of DOC and $a_{254}$ in the lower lake was $6.04 \pm 0.15 \mathrm{mg} \mathrm{L}^{-1}$ and 30.63 \pm 0.90 , which had exceeded that in the upper lake. This result indicated that the concentration of DOM in Nansi Lake had a decided spatial variability under the influence of hydrological changes. And the spatial distribution of SUVA changed over time, which suggested aromaticity of DOM also altered obviously (Fig. 3g-i). 
Table 1

spectral parameters of DOM collected from the upper lake and lower lake of Nansi Lake derived from UV-Vis and fluorescent spectroscopy.

\begin{tabular}{|c|c|c|c|c|c|c|c|c|}
\hline area & time & DOC & a254 & HIX & $\begin{array}{l}F_{\max } \\
\text { (humic- } \\
\text { like) }\end{array}$ & $\begin{array}{l}\text { \% } F_{\max } \\
\text { (humic- } \\
\text { like) }\end{array}$ & $\begin{array}{l}F_{\text {max }} \\
\text { (protein- } \\
\text { like) }\end{array}$ & $\begin{array}{l}\% \mathrm{~F}_{\text {max }} \\
\text { (protein- } \\
\text { like) }\end{array}$ \\
\hline \multirow[t]{3}{*}{$\begin{array}{l}\text { The upper } \\
\text { lake }\end{array}$} & April & $\begin{array}{l}6.60 \pm \\
0.29\end{array}$ & $\begin{array}{l}22.32 \pm \\
0.75\end{array}$ & $\begin{array}{l}2.23 \pm \\
0.06\end{array}$ & $\begin{array}{l}0.89 \pm \\
0.03\end{array}$ & $\begin{array}{l}55.61 \% \\
\pm 1.23 \%\end{array}$ & $\begin{array}{l}0.72 \pm \\
0.03\end{array}$ & $\begin{array}{r}44.39 \% \\
\pm 1.23 \%\end{array}$ \\
\hline & July & $\begin{array}{l}5.86 \pm \\
0.13\end{array}$ & $\begin{array}{l}29.63 \pm \\
0.86\end{array}$ & $\begin{array}{l}2.38 \pm \\
0.11\end{array}$ & $\begin{array}{l}1.47 \pm \\
0.03\end{array}$ & $\begin{array}{l}57.47 \% \\
\pm 1.27 \%\end{array}$ & $\begin{array}{l}1.10 \pm \\
0.05\end{array}$ & $\begin{array}{l}42.53 \% \\
\pm 1.27 \%\end{array}$ \\
\hline & October & $\begin{array}{l}6.08 \pm \\
0.10\end{array}$ & $\begin{array}{l}29.58 \pm \\
0.59\end{array}$ & $\begin{array}{l}3.10 \pm \\
0.05\end{array}$ & $\begin{array}{l}1.61 \pm \\
0.03\end{array}$ & $\begin{array}{l}66.56 \% \\
\pm 0.58 \%\end{array}$ & $\begin{array}{l}0.80 \pm \\
0.01\end{array}$ & $\begin{array}{l}33.44 \% \\
\pm 0.58 \%\end{array}$ \\
\hline \multirow[t]{3}{*}{$\begin{array}{l}\text { The lower } \\
\text { lake }\end{array}$} & April & $\begin{array}{l}5.81 \pm \\
0.22\end{array}$ & $\begin{array}{l}17.92 \pm \\
0.29\end{array}$ & $\begin{array}{l}1.06 \pm \\
0.05\end{array}$ & $\begin{array}{l}0.70 \pm \\
0.02\end{array}$ & $\begin{array}{l}29.98 \% \\
\pm 1.56 \%\end{array}$ & $\begin{array}{l}1.84 \pm \\
0.13\end{array}$ & $\begin{array}{l}70.02 \% \\
\pm 1.56 \%\end{array}$ \\
\hline & July & $\begin{array}{l}6.04 \pm \\
0.15\end{array}$ & $\begin{array}{l}30.63 \pm \\
0.90\end{array}$ & $\begin{array}{l}1.68 \pm \\
0.05\end{array}$ & $\begin{array}{l}1.45 \pm \\
0.03\end{array}$ & $\begin{array}{l}49.34 \% \\
\pm 0.86 \%\end{array}$ & $\begin{array}{l}1.49 \pm \\
0.04\end{array}$ & $\begin{array}{l}50.66 \% \\
\pm 0.86 \%\end{array}$ \\
\hline & October & $\begin{array}{l}5.79 \pm \\
0.18\end{array}$ & $\begin{array}{l}26.79 \pm \\
0.88\end{array}$ & $\begin{array}{l}2.62 \pm \\
0.08\end{array}$ & $\begin{array}{l}1.53 \pm \\
0.04\end{array}$ & $\begin{array}{l}61.98 \% \\
\pm 0.99 \%\end{array}$ & $\begin{array}{l}0.94 \pm \\
0.03\end{array}$ & $\begin{array}{l}28.02 \% \\
\pm 0.99 \%\end{array}$ \\
\hline
\end{tabular}

\subsection{Variations of DOM fluorescence}

As shown in Fig. 4, results of Synchronous fluorescence (SF) spectra suggested that fluorescence intensity of different substances was discrepant in Nansi Lake in April, July and October. For the upper lake, the weak fluorescence intensity of humic-like substances was found in April rather than July and October, while weak fluorescence intensity of protein-like substances occurred in October instead of April and July (Fig. 4a and b). A similar phenomenon was also found in the lower lake (Fig. 4c and d).

A total of four visible fluorescence peaks were found in EEM spectra (Fig. 5). Peak T and peak D are located in Ex/Em: $320 / 280 \mathrm{~nm}$ and 320/220 nm, which might be related to the existence of protein-like substances, respectively. Peak A (Ex/Em: 410/240 nm) and peak C (Ex/Em: 450/350 nm) could be ascribed to humic-like substances. There were some regularly changes of EEM results in Nansi Lake from April to October.

As shown in Fig. 5a and d, peak A in DOM collected from the upper lake seems to have a more stronger fluorescence intensity compared with other peaks, which implying that fulvic- and humic-like substances might have an important effect on the DOM property in April for the upper lake. Fluorescence intensity of peak $A$ was still pretty obvious in the lower lake, but stronger fluorescence intensity of peak $T$ and peak $D$ was found compared with the upper lake (Fig. $5 \mathrm{~g}$ and j). This result indicated that DOM property in the two areas might have some significant differences in April. Fluorescence intensity of peak $A, T$ and $D$ in both the two areas in Nansi Lake was significantly enhanced in July(Fig. 5b, e, h and k). When it came to 
October, fluorescence intensity of peak A was stronger than July, while fluorescence intensity of peak T and D was weakened (Fig. 5c, f, i and I). Results of EEM spectra were similar to SF spectra.

To quantificat the difference of DOM in Nansi Lake under the different hydrological condition, a fivecomponent (C1-C5) PARAFAC model was identified and inspected by split-half analysis (Fig. 6). C1-5 are located in Ex/Em: 230/420 nm, Ex/Em: (270)320/450 nm, Ex/Em: (240)300/380 nm, Ex/Em: (< 225)275/320 nm and Ex/Em: 230/340 nm, respectively. Positions of C1-3 are close to the position of peak $A$ and peak $C$ in EEM spectra, which could be classified to humic-like components. Meanwhile, $C 4$ and $\mathrm{C} 5$ are mainly correspond to the existence of protein-like peak $T$ and peak D in EEM spectra (DeVilbiss et al., 2016; Yang et al., 2019; Mclntyre and Guéguen, 2013; Santín et al., 2009; Yamashita and Jaffe, 2008; de Zarruk et al., 2007; Tang et al., 2019; Yamashita et al., 2013). The result of EEM-PARAFAC analysis indicated a complex material construction of DOM in Nansi Lake. And there is no doubt that the property of DOM was mainly controlled by changes of those components.

According to the values of fluorescence intensity $\left(F_{\max }\right)$ of different substances, visible differences were found in the two areas of Nansi Lake (Fig. 7a-f and Table 1). Mean values of $F_{\max }$ of humic-like substances (C1-C3) in April, July and October were $0.89 \pm 0.03,1.47 \pm 0.03,1.61 \pm 0.03$ in the upper lake, and $0.70 \pm 0.02,1.45 \pm 0.03,1.53 \pm 0.04$ for the lower lake, respectively. $F_{\max }$ of humic-like substances (C1-C3) in the upper lake was always higher than the lower lake. However, $F_{\max }$ of protein-like substances (C4 and C5) in the two areas was the opposite of humic-like substances. The lower lake always had higher values of $F_{\max }$ of protein-like substances in these three months. Principal component analysis (PCA) analysis was applied to explain time variation of relative abundance of PARAFAC components $\left(\% F_{\text {max }}\right)$ in Nansi Lake (Fig. 8). There were two components in PCA analysis (PCA1 and PCA2), which could explain $73.5 \%$ and $22.4 \%$ of the total variance, respectively. Compared with October, Nansi Lake was more affected by protein-like components $\mathrm{C} 4$ and $\mathrm{C} 5$ in April and July. However, when it came to October, Nansi Lake was mainly controlled by humic-like substances C1, C2 and C3 (Fig. 7g-l and Fig. 8). PCA result indicated that the contribution of protein-like substances in April and July was higher than that in October, which was consistent with EEM. But it should be noticed that the upper lake and lower lake are affected by different substances to different degrees in April and July. All these results suggested that material construction of DOM in Nansi Lake had some differences both in the time and spatial scale.

Fluorescence index (FI, BIX and HIX) was shown in Fig. 7m-u and Table 1, and the contribution of sources to DOM in Nansi Lake had some distinct distinctions. Compared with changes of FI and BIX in the upper lake and lower lake, variation of HIX was more obvious in the two areas of Nansi Lake. In April, the mean value of HIX was $2.23 \pm 0.06$ for the upper lake and $1.06 \pm 0.05$ for the lower lake, which suggested that the degree of humification was significantly higher than that in the lower lake $(p<0.01)$ when water was diverted up to Nansi Lake from other lakes (Fig. 8a). Most of the water stored in Nansi Lake had been transferred in July, and at this period, the mean value of HIX in the upper lake and the lower lake was $2.38 \pm 0.11,1.68 \pm 0.05$, respectively (Fig. $8 b$ ). When it came to October, mean value of this index had become to $3.10 \pm 0.05$ in the upper lake and $2.62 \pm 0.08$ in the lower lake (Fig. 8c). Although mean values 
of HIX in the upper lake were always higher than the lower lake from April to October, it should be noticed that the holistic degree of humification in Nansi Lake was a rising trend. This result might be related to changes in substance content.

\subsection{Relevancy between components and indices of DOM}

Correlation analysis was employed to find factors that generated the discrepant DOM property. As shown in Fig. 9, significant positive correlations were found between humic-like component $\mathrm{C} 1, \mathrm{C} 2$ and $\mathrm{C} 3$ ( $p<$ 0.001), which indicated that the origin of humic-like substances in Nansi Lake might be analogical. Relations between protein-like components C4 and C5 was not prominent, which suggested that sources of protein-like substances in Nansi Lake might be different. However, significant correlations were observed between humic-like substances $\mathrm{C} 2, \mathrm{C} 3$ and protein-like component C4 $(p<0.001)$. And this result indicated that different substances have a certain homology in Nansi Lake. The highly positive correlation between HIX and humic-like substances (C1-C3) illustrated that the degree of humification was always linked to the abundance of humic-like substances $(p<0.001)$.

In addition, we found that linear relationship between PARAFAC components and DOM concentration had some different in April, July and October. The linear relationships between PARAFAC components and DOC, $a_{254}$ were the most significant in April (Fig. 10a and b). Among all the PARAFAC components, humic-like component C2 had the best linear relationship with DOC $\left(R^{2}=0.35, p<0.001\right)$ and $a_{254}\left(R^{2}=\right.$ $0.78, p<0.001$ ), which suggested the concentration of DOM in April was mainly determined by humic-like component $C 2$. And the linear relationship between $a_{254}$ and humic-like components $C 2\left(R^{2}=0.09, p<\right.$ $0.05), C 3\left(R^{2}=0.11, p<0.01\right)$ also indicated that humic-like substances and DOM concentration were inseparable in July (Fig. 10b). When it came to October, visible positive correlations were found between DOC and protein-like component C5 $\left(\mathrm{R}^{2}=0.08, p<0.05\right), a_{254}$ and humic-like component $\mathrm{C} 2\left(\mathrm{R}^{2}=0.05, p\right.$ $<0.05)$. This result suggested that both humic- and protein-like substances were related to the DOM concentration of Nansi Lake in October, which was diverse compared with April and July.

\section{Discussion}

\subsection{Possible reasons for the spatial variation of DOM in Nansi Lake}

Just like most lakes and rivers with a dam, there are always some distinct differences between upstream and downstream (Tombolini et al., 2014; Talukdar et al., 2020; Maavara et al., 2020). Our results suggested that DOM properties in the two areas of Nansi Lake were discrepant. However, these results were not solely attributable to the dam in Nansi Lake. And there are many reasons for differences in DOM property.

Most of industrial areas as well as rivers that flowing into Nansi Lake are mainly distributed in the north of the lake, which might bring a lot of pollutants (Lv et al., 2014; Zhuang et al., 2014). Based on the land 
use classified in Nansi Lake watershed, we found that the proportion of hominine land use (\%urban + $\%$ cropland) exceeded that of other types. And basin of hominine land use could output humic-like substances from rivers to lakes (Morling et al., 2017; Shi et al., 2019). High values of $F_{\max }$ and $\% F_{\max }$ of humic-like substances found in the upper lake in April, July and October might be relative to these exogenetic contaminants. And the degree of humification in the upper lake seems to prove it as well. As a result of the uneven distribution of the main rivers and industrial areas, DOM characteristics in different areas of Nansi Lake may still have some spatial differences even if the dam did not exist. However, presence of the dam could impact on the hydrological connectivity as well as the flow of nutrients, which might exacerbate the discrepancy in Nansi Lake (Rolls and Bond, 2017; Mori et al., 2018; Almeida et al., 2020).

\subsection{Possible reasons for the temporal variation of DOM in Nansi Lake}

For most of the macrophyte-dominated lakes that could easily found in northern China, just like Nansi Lake, a large amount of protein-like substances and heavy metals would be released in a concentrated manner in May to July because of the death and decomposition of submerged plants (Deng et al., 2016). The strong fluorescence intensity of protein-like substances both in the upper lake and the lower lake was found in July, which might be related to the releases of submerged plants (Table 1).

Nevertheless, our results suggested that the highest $\% F_{\max }$ of protein-like substances were occurred in April rather than July, which implied that the higher content of protein-like substances in April might not be associated with the death and decomposition of submerged plants (Table 1). According to the information announced by Ministry of Water Resources of the People's Republic of China, the yearly work to divert water from the southern lakes to Nansi Lake ended on May 28, 2019. It also means that a lot of water equipped in Nansi Lake in April was still mainly due to receiving water from the southern lakes. The previous study found that Gaoyou Lake and Hongze Lake, the mainly two impounded lakes of SNWDP, which were both located south of Nansi Lake, had several times as much turbid, total suspended solids and chlorophyll a as Nansi Lake (Guo et al., 2020b). Fluorescence intensity of protein-like substances was rarely seen in cleanly water, which could forecast the degree of contamination in the water body (Baker, 2002). High content of protein-like substances in April might be associated with the input of relative unclean water from other lakes. With the completion of the water transfer to Nansi Lake in May 2019, rainfalls and rivers flowing become the main sources of water supply to Nansi Lake. And DOM properties in the two areas of Nansi Lake had a similar change trend with the change of the main water source. $\% F_{\max }$ of protein-like substances decreased from $44.39 \% \pm 1.23-33.44 \% \pm 0.58 \%$ for the upper lake and $70.02 \% \pm 1.56-28.02 \% \pm 0.99 \%$ for the lower lake, respectively. As opposed to protein-like substances, $\% F_{\max }$ of humic-like substances increased from $55.61 \% \pm 1.23-66.56 \% \pm 0.58 \%$ for the upper lake and $29.98 \% \pm 1.56-61.98 \% \pm 0.99 \%$ for the lower lake, respectively. This change indicated that DOM in Nansi Lake was greatly affected by exogeneity. And significant correlations between humic-like substances, DOC and $a_{254}$ can also verify it. 


\subsection{DOM variation's enlightenment to the management of heavy metals}

Compared with overlying water, sediments were considered as a major sink and source of pollutants (Devesa-Rey and Barral, 2011; Sheykhi and Moore, 2013). Great fluctuation of water level might lead destabilization of surface sediments in a shallow lake, which could release pollutants from sediments and make the aquatic environment more complex (Zhu et al., 2015). Previous study found that the concentration of several type heavy metals in the lower lake was higher than the upper lake, which was different from ten years ago (Zhuang et al., 2019). Distribution variation of heavy metals in Nansi Lake might be related to suspended particulate matter, soil erosion and other reasons caused by the SNWTP (Zhuang et al., 2019). Furthermore, our previous research suggested that both the humic- and protein-like substances in the lower lake had a stronger metal-binding compared with the upper lake (Ren et al., 2020). Differences in the metal-binding ability of DOM could affect the migration of heavy metals (Xu et al., 2019). Therefore, distribution variation of heavy metals in Nansi Lake might also be inseparable from the difference of DOM properties. Although it is difficult to conclude all factors that influence the distribution of heavy metals, we suggest that government departments should consider the impact of DOM, especially significantly difference of DOM properties under the influence of SNWTP, when dealing with problems about heavy metals.

\section{Conclusions}

Due to influences of the dam and the eastern route of China's South-to-North Water Diversion Project (SNWDP), differences of water level in Nansi Lake were distinct in April, July and October 2019. HIX in the upper lake was always higher than the lower lake from April to October, suggesting that the degree of humification in the upper lake was always higher than it in the lower lake. And the holistic degree of humification both in the two areas was a rising trend over time.

Combining EEM and PARAFAC analysis, a total of five fluorescent components were obtained, including three humic-like components (C1-C3) and two protein-like components (C4 and C5). On a temporal scale, DOM properties were discrepant under the different hydrological condition. In April, the proportion of protein-like substances exceeded that it in July and October. The proportion of humic-like substances increased gradually in Nansi Lake after April. When it came to October, humic-like substances become the mainly substances both in the two areas of Nansi Lake.

\section{Declarations}

Author information

\section{Affiliations}

School of Environment and Planning, Liaocheng University, Liaocheng 252000, China 
Haoyu Ren, Xin Yao, Feiyang Ma, Tuantuan Fan, Huanguang Deng \Yinghao Zhang

Taihu Laboratory for Lake Ecosystem Research, State Key Laboratory of Lake Science and Environment, Nanjing Institute of Geography and Limnology, Chinese Academy of Sciences, Nanjing 210008, China

Xin Yao

\section{Contributions}

Haoyu Ren: Writing - original draft, Formal analysis, Investigation; Xin Yao: Writing - review \& editing; Feiyang Ma: Data curation, Formal analysis; Tuantuan Fan: Data curation, Formal analysis; Huanguang Deng: Methodology, Software; Yinghao Zhang: Methodology, Software.

\section{Corresponding authors}

Correspondence to $\underline{\text { Xin Yao. }}$.

\section{Data availability}

They are all publically available.

\section{Funding}

We gratefully thank the National Natural Science Foundation of China (41977322, 41901120), Open research Foundation of the State Key Laboratory of Lake Science and Environment, Chinese Academy of Sciences (2018SKL004), and Natural Science Foundation of Shandong Province, China (ZR2019BD052) for their support on this study.

\section{Compliance with ethical standards}

Competing interests None.

Ethics approval Not applicable.

Consent to participate All of the authors consented to participate in the drafting of this manuscript.

Consent to publish All of the authors consented to publish this manuscript.

\section{References}

Almeida, R. M., Barros, N., Cole, J. J., et al., 2020. Emissions from amazonian dams. Nature Climate Change, 3(12), 1005.

Andrew, A. A., Vecchio, R. D., Subramaniam, A., et al., 2013. Chromophoric dissolved organic matter (CDOM) in the Equatorial Atlantic Ocean: Optical properties and their relation to CDOM structure and source. Marine Chemistry, 148, 33-43. 
Baker, A., 2002. Fluorescence excitationemission matrix characterization of river waters impacted by a tissue mill effluent. Environmental ence \& Technology, 36(7), 1377-82.

Bai, L., Zhao, Z., Wang, C., et al., 2017. Multi-spectroscopic investigation on the complexation of tetracycline with dissolved organic matter derived from algae and macrophyte. Chemosphere 187, 421429

Bai, L., Zhang, Q., Ju, Q., et al., 2020. Priming effect of autochthonous organic matter on enhanced degradation of 17a-ethynylestradiol in water-sediment system of one eutrophic lake. Water Research, 184, 116153.

Carr, N., Davis, C. E., Blackbird, S., et al., 2019. Seasonal and spatial variability in the optical characteristics of DOM in a temperate shelf sea. Progress in Oceanography, 177, 101929.

Cheimonopoulou, M.T., Bobori, D.C., Theocharopoulos, I., Lazaridou, M., 2011. Assessing ecological water quality with macroinvertebrates and fish: a case study from a small Mediterranean river. Environ. Manag. 47 (2), 279-290

Chen, M., Jaffe, R., 2014. Photo- and bio-reactivity patterns of dissolved organic matter from biomass and soil leachates and surface waters in a subtropical wetland. Water Res. 61, 181-190.

Devesa-Rey, R., Barral, M. T., 2012. Allochthonous versus autochthonous naturally occurring organic matter in the Anllóns river bed sediments (Spain). Environmental Earth Sciences.

DeVilbiss, S.E., Zhou, Z.Z., Klump, J.V., Guo, L.D., 2016. Spatiotemporal variations in the abundance and composition of bulk and chromophoric dissolved organic matter in seasonally hypoxia-influenced Green Bay, Lake Michigan, USA. Sci. Total Environ. 565, 742-757.

Deng, H.G., Zhang, J., Chen, S.Y., et al., 2016. Metal release/accumulation during the decomposition of Potamogeton crispus in a shallow macrophytic lake. Environ. Sci. 42, 71-78.

Guo, C. B., Chen, Y. S., Xia, W. T., et al., 2020a. Eutrophication and heavy metal pollution patterns in the water suppling lakes of China's south-to-north water diversion project. Sci. Total Environ. 711(1), 134543.

Guo, C. B., Chen, Y. S., Gozlan, R. E., et al., 2020b. Patterns of fish communities and water quality in impounded lakes of China's south-to-north water diversion project. Sci. Total Environ. 713.

Huguet, A., Vacher, L., Relexans, S., et al., 2009. Properties of fluorescent dissolved organic matter in the Gironde Estuary. Org Geochem. 40 (6), 706-719.

Hur, J., Lee, B.-M., 2011. Characterization of binding site heterogeneity for copper within dissolved organic matter fractions using two-dimensional correlation fluorescence spectroscopy. Chemosphere, 83(11), 1603-1611. 
Liu, D., Du, Y., Yu, S., et al., 2020. Human activities determine quantity and composition of dissolved organic matter in lakes along the Yangtze River. Water Research, 168, 115132.

Lv, J., Zhang, Z., Li, S., et al., 2014. Assessing spatial distribution, sources, and potential ecological risk of heavy metals in surface sediments of the nansi lake, eastern china. Journal of Radioanalytical and Nuclear Chemistry, 299(3), 1671-1681.

Maavara, T., Chen, Q., et al., 2020. River dam impacts on biogeochemical cycling. Nature Reviews Earth \& Environment.

Mclntyre, A.M., Guéguen, C., 2013. Binding interactions of algal-derived dissolved organic matter with metal ions. Chemosphere 90, 620-626.

Mori, T., Onoda, Y., Kayaba, Y., 2018. Geographical patterns of flow-regime alteration by flood-control dams in Japan. Limnology 19 (1), 53-67.

Morling, K., Herzsprung, P., Kamjunke, N., 2017. Discharge determines production of, decomposition of and quality changes in dissolved organic carbon in pre-dams of drinking water reservoirs. Sci. Total Environ. 577 (15), 329-339.

Noda, I., 2016. Techniques useful in two-dimensional correlation and codistribution spectroscopy (2DCOS and 2DCDS) analyses. J. Mol. Struct. 29-41.

Ren, H. Y., Ma, F. Y., Yao, X., et al., 2020. Multi-spectroscopic investigation on the spatial distribution and copper binding ability of sediment dissolved organic matter in Nansi Lake, China. Journal of Hydrology, $591,125289$.

Rolls, R.J., Bond, N.R., 2017. Environmental and ecological effects of flow alteration in surface water ecosystems. In: Water for the Environment. Academic Press, pp. 65-82.

Santín, C., Yamashita, Y., Otero, X.L., Álvarez, M.Á., Jaffé, R., 2009. Characterizing humic substances from estuarine soils and sediments by excitation-emission matrix spectroscopy and parallel factor analysis. Biogeochemistry 96 (1), 131-147.

Sheykhi, V., Moore, F., 2013. Evaluation of potentially toxic metals pollution in the sediments of the Kor river, southwest Iran. Environ. Monit. Assess. 185 (4), 3219-3232.

Shi, Y., Zhang, L., Li, Y., et al., 2019. Influence of land use and rainfall on the optical properties of dissolved organic matter in a key drinking water reservoir in china. Sci. Total Environ. 699, 134301.

Shin, Y., Lee, E.-J., Jeon, Y.-J., et al., 2016. Hydrological changes of DOM composition and biodegradability of rivers in temperate monsoon climates. Journal of Hydrology, 540, 538-548. 
Talukdar, S., Pal, S., Chakraborty, A., Mahato, S., 2020. Damming effects on trophic and habitat state of riparian wetlands and their spatial relationship. Ecological Indicators 118.

Tang, J., Li, Z., Yu, Z., liu, X.M., Wang, Y.Q., Wen, P., Zhou, S.G., 2019. Insight into complexation of Cu(II) to hyperthermophilic compost-derived humic acids by EEM-PARAFAC combined with heterospectral two dimensional correlation analyses. Sci. Total Environ. 656, 29-38.

Tank, J.L., Rosi-Marshall, E.J., Griffiths, N.A., Entrekin, S.A., Stephen, M.L., 2010. A review of allochthonous organic matter dynamics and metabolism in streams. North Am. Benthol. Soc. 29, 118-146.

Tombolini, I., Caneva, G., Cancellieri, L., et al., 2014. Damming effects on upstream riparian and aquatic vegetation: the case study of nazzano (tiber river, central italy). Knowledge \& Management of Aquatic Ecosystems(412), 350-353.

Xu, H. C., Zou, L., Guan, D. X., et al., 2019. Molecular weight-dependent spectral and metal binding properties of sediment dissolved organic matter from different origins. Sci. Total Environ. 665, 828-835.

Yamashita, Y., Boyer, J.N., Jaffé, R., 2013. Evaluating the distribution of terrestrial dissolved organic matter in a complex coastal ecosystem using fluorescence spectroscopy. Cont. Shelf Res. 66, 136-144.

Yamashita, Y., Jaffé, R., 2008. Characterizing the interactions between trace metals and dissolved organic matter using excitation-emission matrix and parallel factor analysis. Environ. Sci. Technol. 42 (19), 7374-7379.

Yang, X.F., Meng, L., Meng, F.G., 2019. Combination of self-organizing map and parallel factor analysis to characterize the evolution of fluorescent dissolved organic matter in a full-scale landfill leachate treatment plant. Sci. Total Environ. 654, 1187-1195.

Yao, X., Wang, S., Ni, Z., et al., 2015. The response of water quality variation in Poyang Lake (Jiangxi, People's Republic of China) to hydrological changes using historical data and DOM fluorescence. Environmental Science and Pollution Research, 22(4), 3032-3042.

Zhang, G., Liu, X., Lu, S., et al., 2020. Occurrence of typical antibiotics in Nansi Lake's inflowing rivers and antibiotic source contribution to Nansi Lake based on principal component analysis-multiple linear regression model. Chemosphere, 242, 125269.

Zhang, Y. L., Zhou, L., Zhou, Y. Q., et al., 2021. Chromophoric dissolved organic matter in inland waters: Present knowledge and future challenges. Sci. Total Environ,759.

Zhou, Y., Xiao, Q., Yao, X., et al., 2018. Accumulation of Terrestrial Dissolved Organic Matter Potentially Enhances Dissolved Methane Levels in Eutrophic Lake Taihu, China. Environmental Science \& Technology, 52(18), 10297-10306. 
Zhou, Y., Zhou, L., Zhang, Y., et al., 2019. Autochthonous dissolved organic matter potentially fuels methane ebullition from experimental lakes. Water Research, 166, 115048.

Zhuang, W., Ying, S. C., Frie, A. L., et al., 2019. Distribution, pollution status, and source apportionment of trace metals in lake sediments under the influence of the south-to-north water transfer project, china. Sci. Total Environ. 671, 108-118.

Zhu, M., Zhu, G., Nurminen, L., Wu, T., et al., 2015. The influence of macrophytes on sediment resuspension and the effect of associated nutrients in a shallow and large Lake (Lake Taihu, China). PLoS One 10, e0127915

de Zarruk, K. K., Scholer, G., Dudal, Y., 2007. Fluorescence fingerprints and Cu2+-complexing ability of individual molecular size fractions in soil-and waste-borne DOM. Chemosphere 69, 540-548.

\section{Figures}

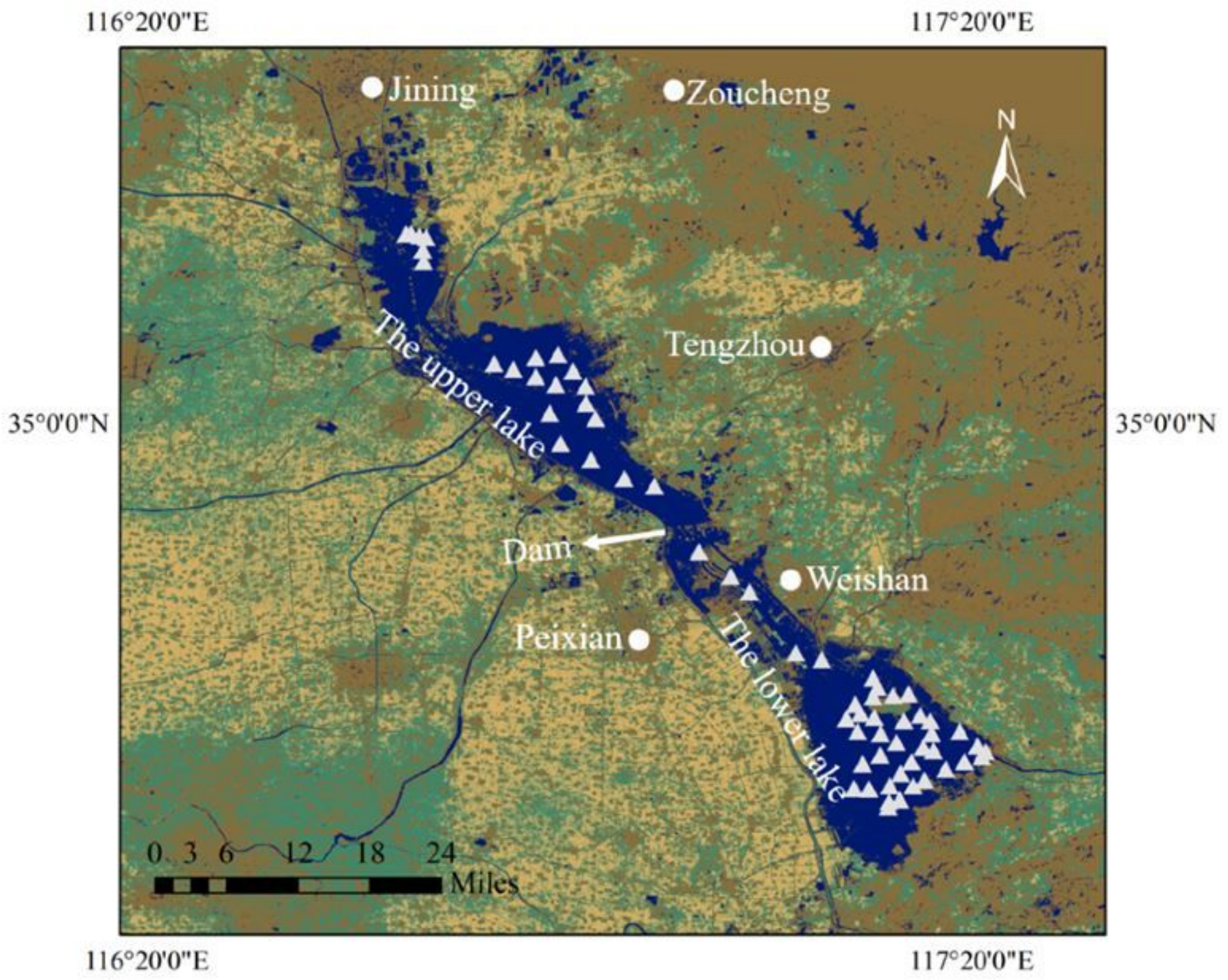


Figure 1

Location of sampling sites in the upper lake and lower lake of Nansi Lake. Note: The designations employed and the presentation of the material on this map do not imply the expression of any opinion whatsoever on the part of Research Square concerning the legal status of any country, territory, city or area or of its authorities, or concerning the delimitation of its frontiers or boundaries. This map has been provided by the authors.

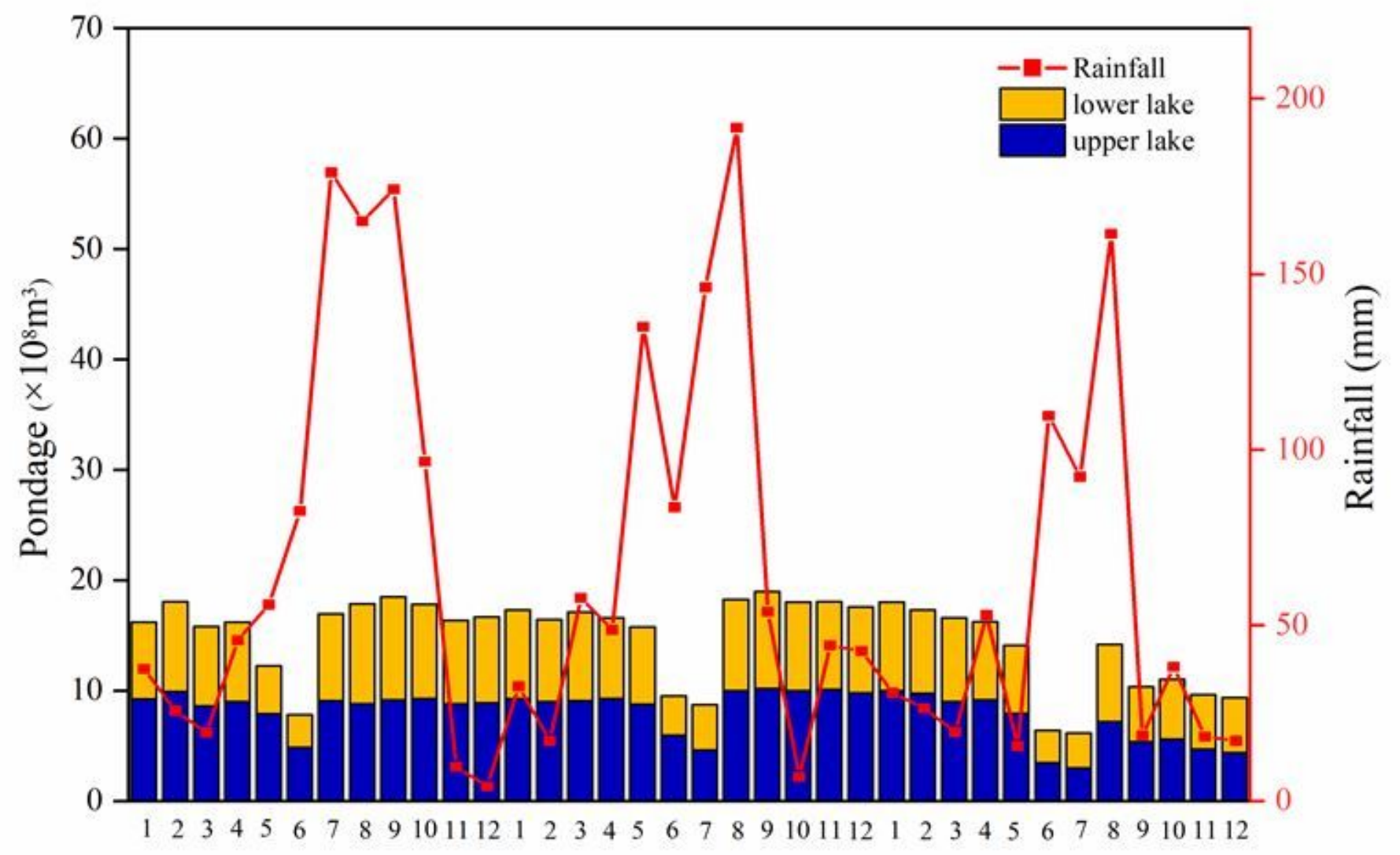

Months from 2017 to 2019

Figure 2

Variations of rainfall and pondage in Nansi Lake from 2017 to 2019. 

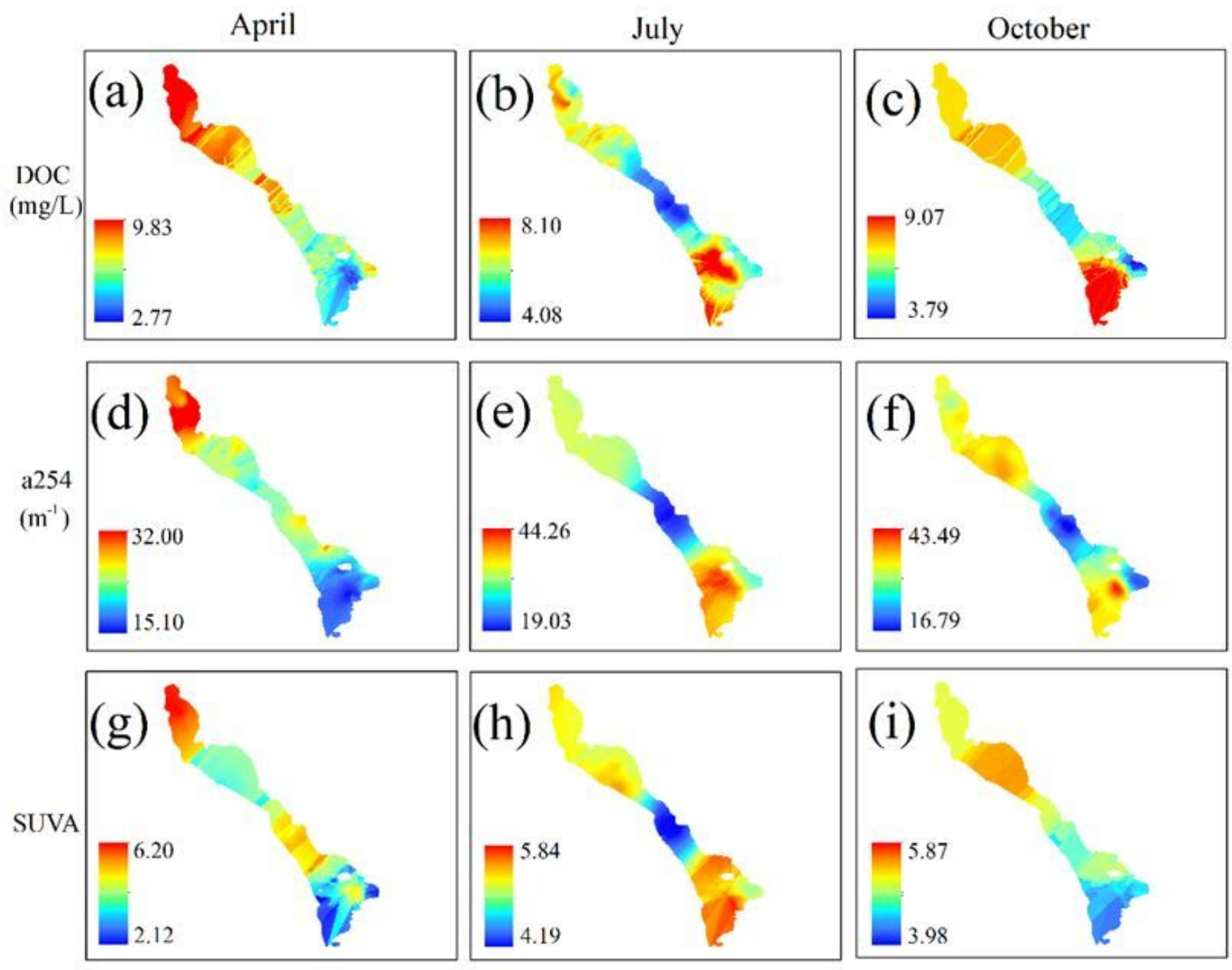

Figure 3

Spatial variability of DOC (a-b), absorption coefficient a254 (d-f) and SUVA (g-h) in April, July and October 2019. 

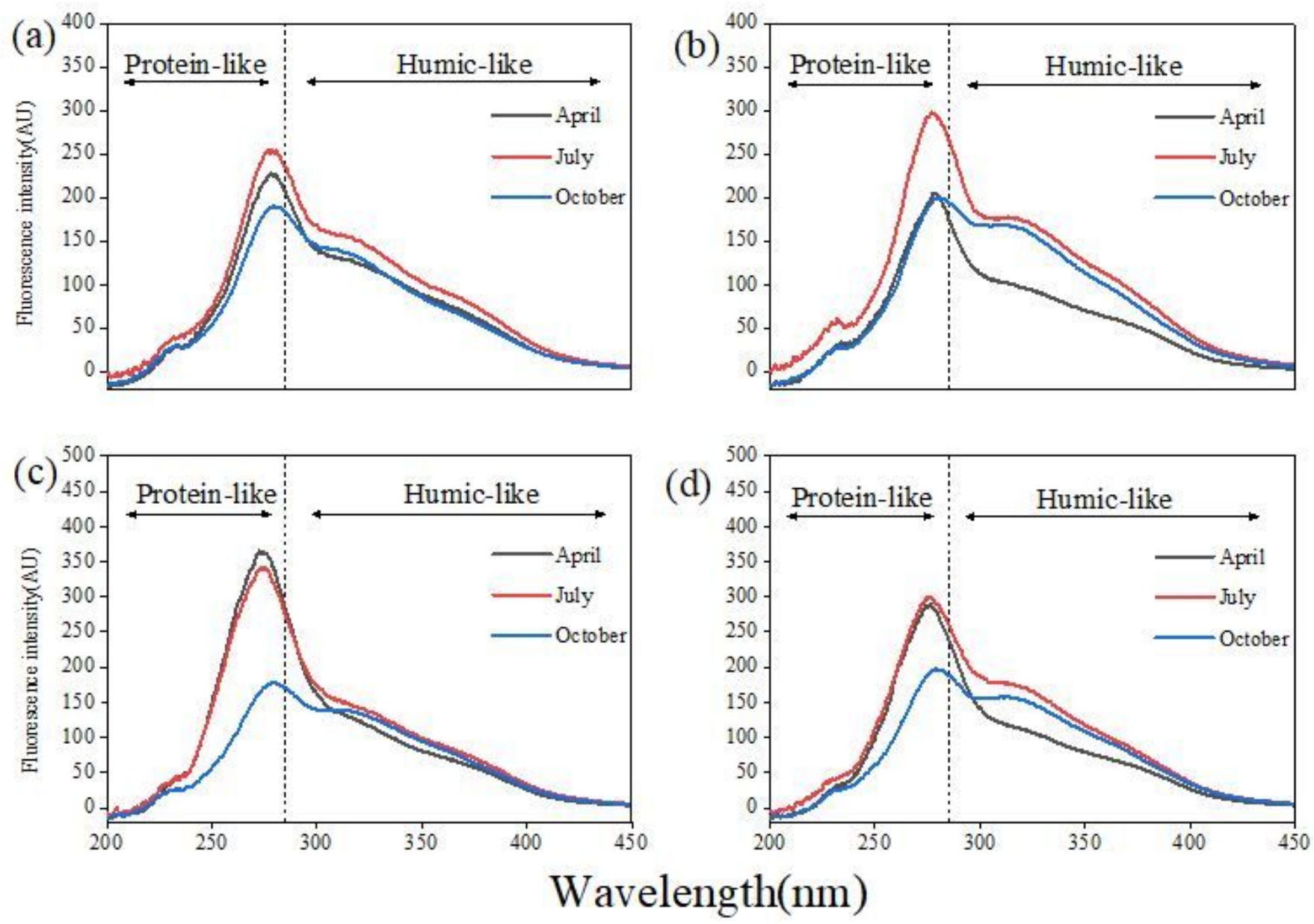

Figure 4

Synchronous fluorescence spectra of DOM collected from the upper lake ( $a$ and $b$ represented two sample sites selected randomly in the upper lake) and the lower lake (c and d represented two sample sites selected randomly in the lower lake) in April, July and October. 

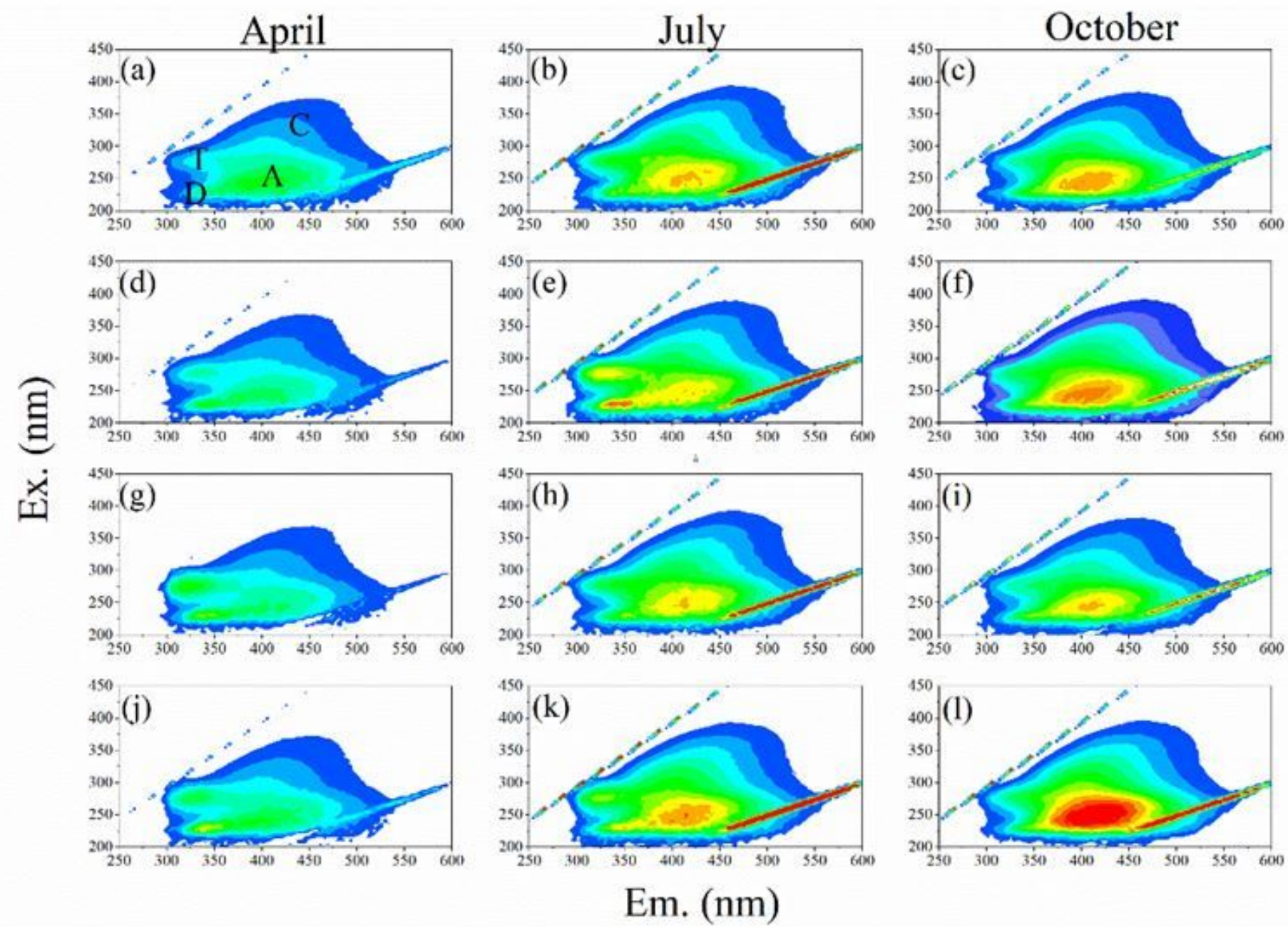

Fluorescence

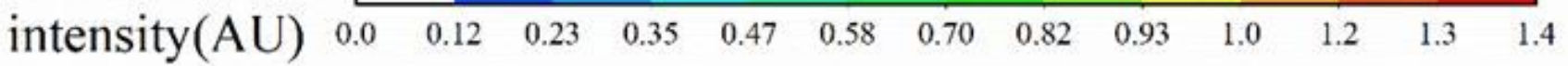

Figure 5

EEM spectra of DOM collected from the upper lake (a-c and d-f represented changes of two sample sites selected randomly in the upper lake under the different hydrological condition) and the lower lake ( $\mathrm{g}$-i and $j-I$ represented changes of two sample sites selected randomly in the lower lake under the different hydrological condition). 

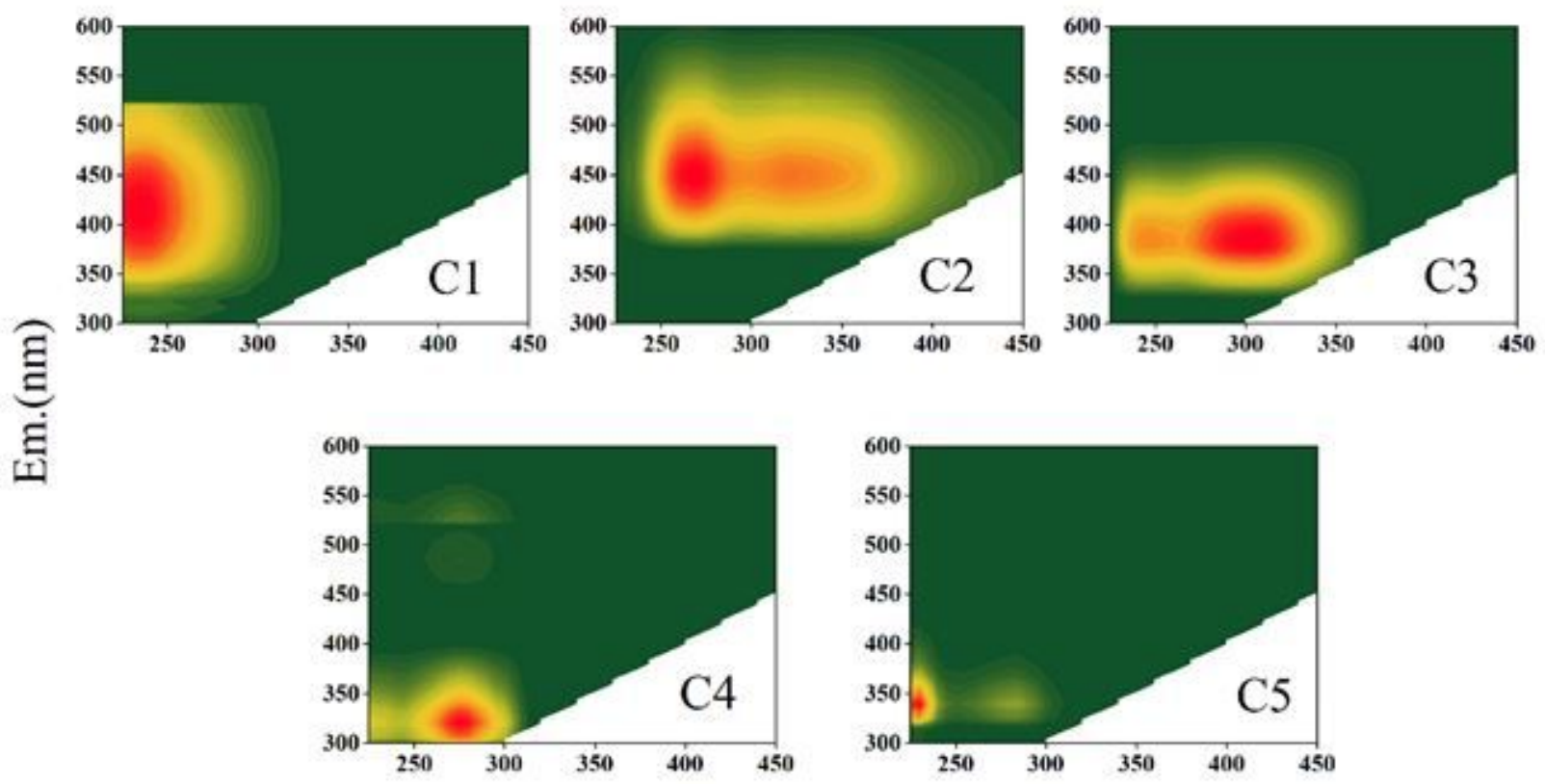

Ex.(nm)

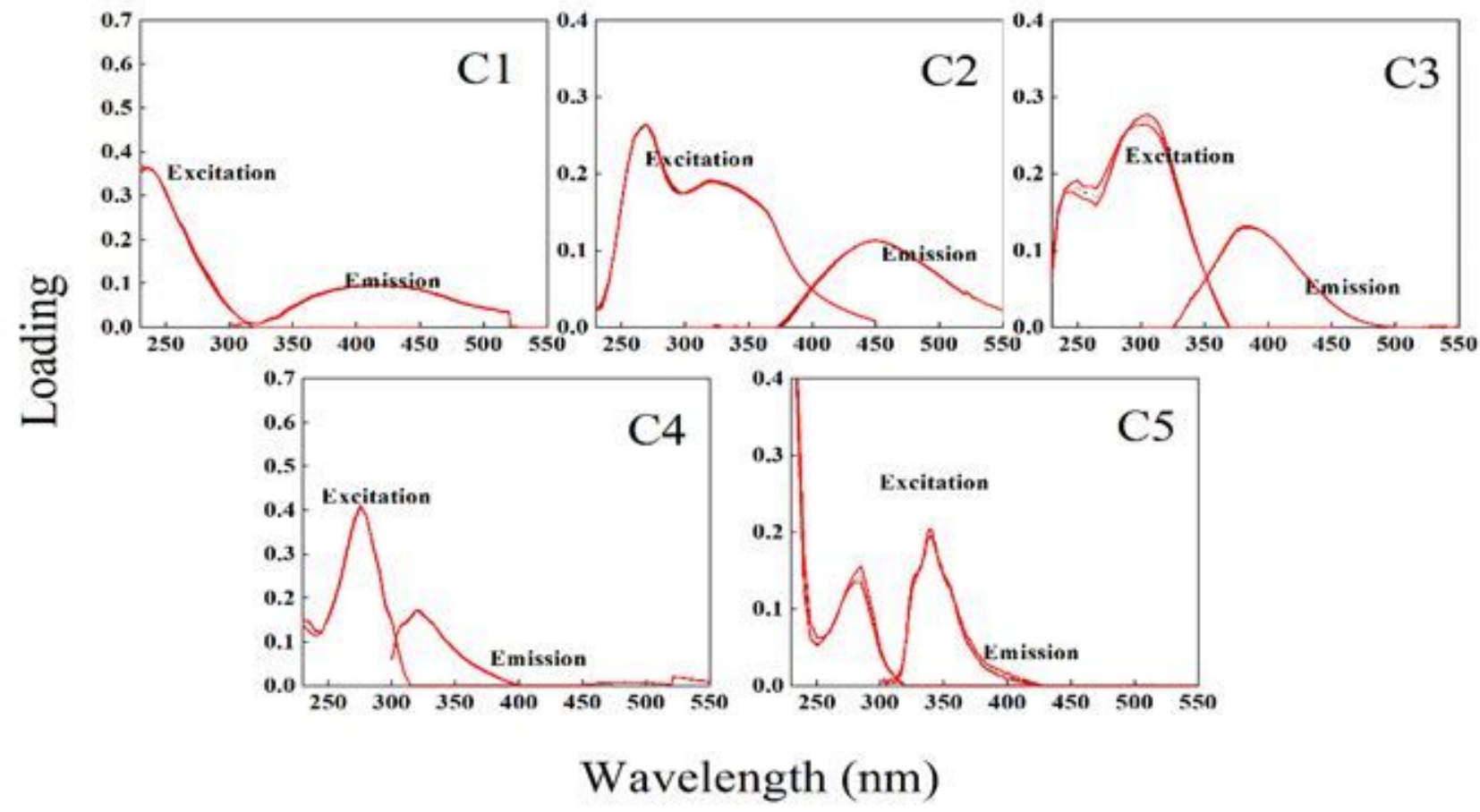

Figure 6

The Ex/Em loadings of the five fluorescent components derived and split-half validated by PARAFAC model. 


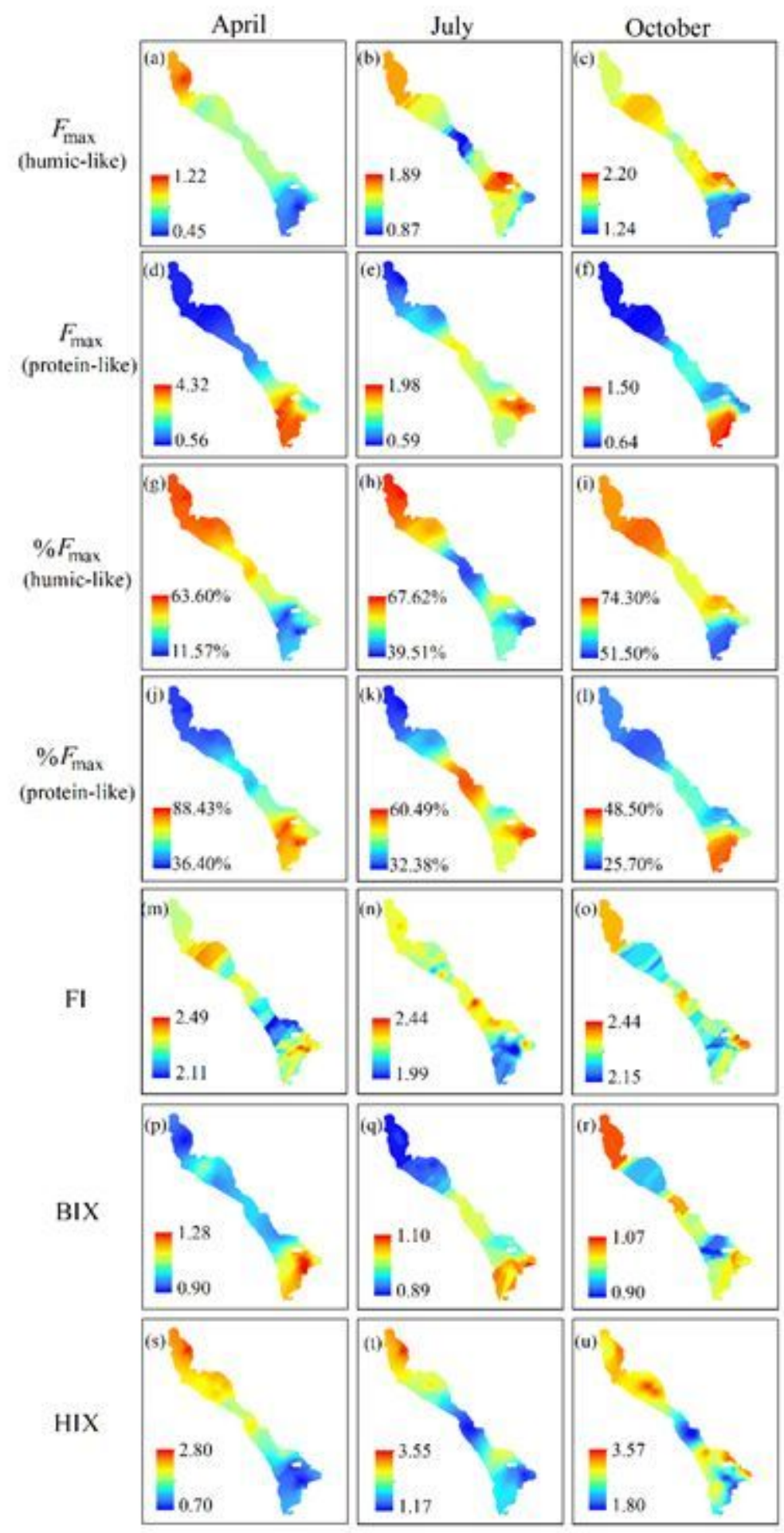

Figure 7

Fluorescence intensity (Fmax), the ratio of the fluorescence intensity of component to the total fluorescence intensity (\%Fmax) and fluorescence index ( $\mathrm{FI}, \mathrm{BIX}$ and $\mathrm{HIX}$ ) distributions of DOM in Nansi Lake in April, July and October. 


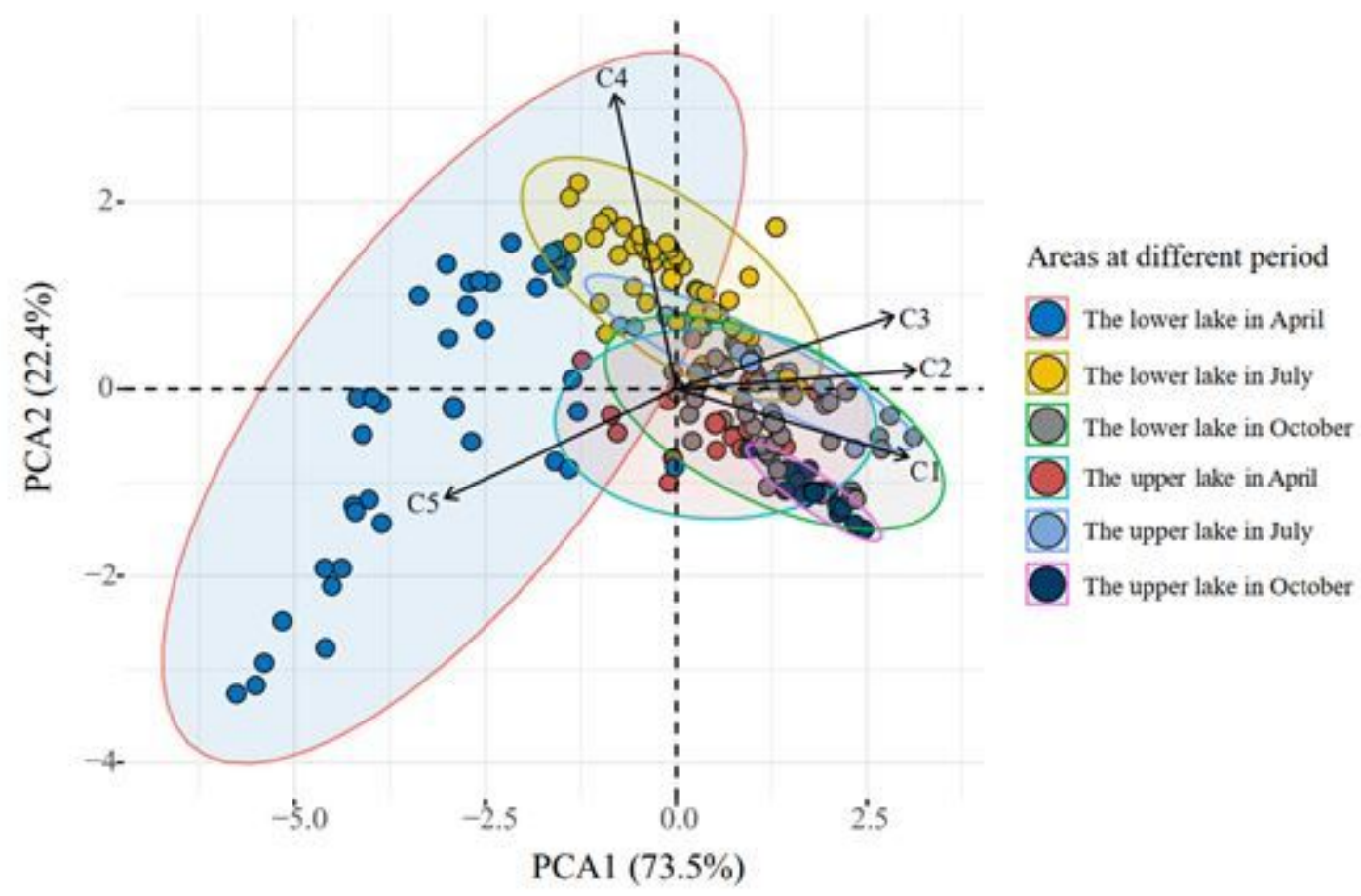

Figure 8

Principal component analysis (PCA) results based on the ratio of the fluorescence intensity of component to the total fluorescence intensity (\%Fmax) in Nansi Lake in April, July and October. 


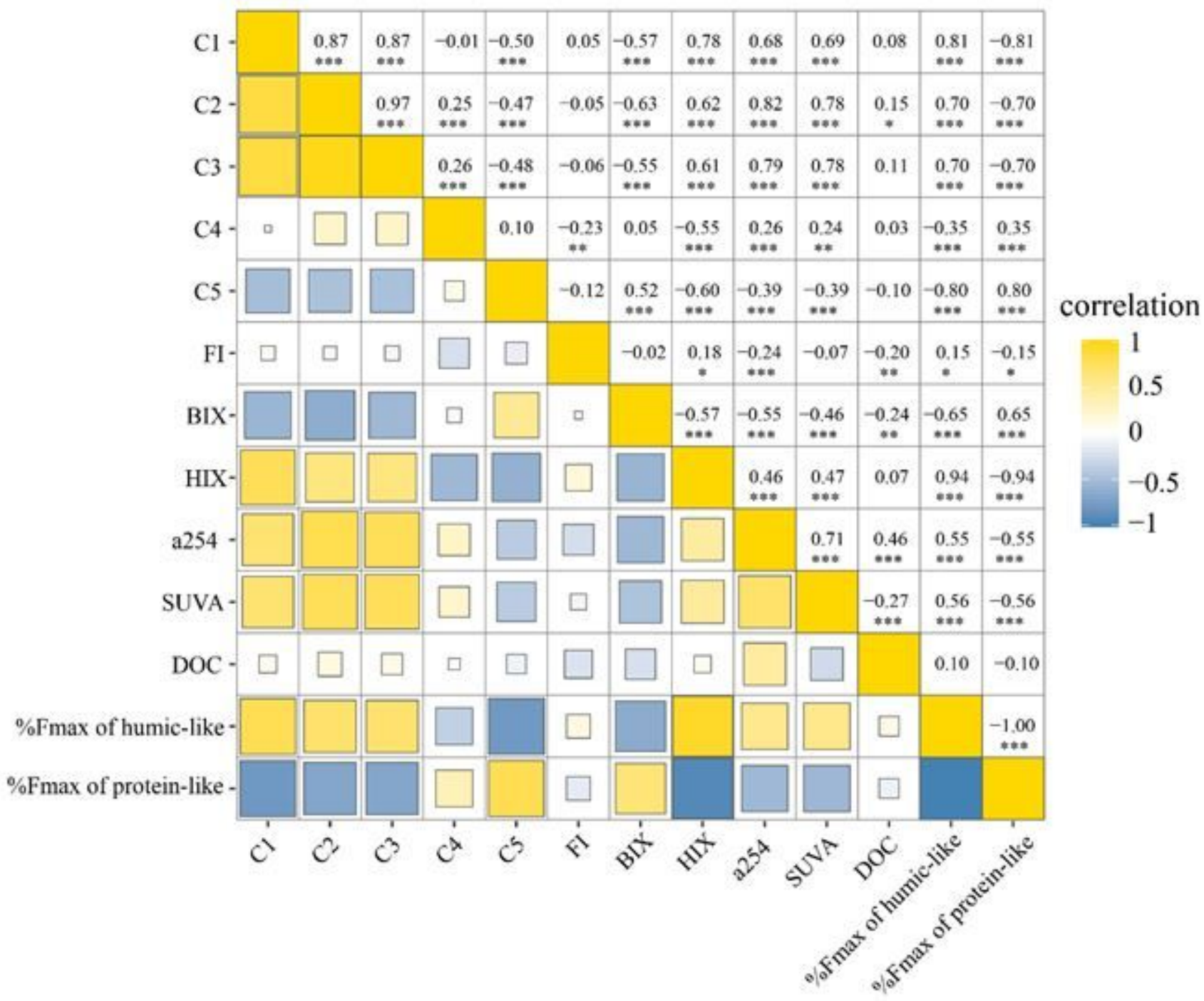

Figure 9

Correlations of spectral characteristic of DOM from Nansi Lake based on EEMs and UV-vis. The magnitude of squares in this graph represented the change in the correlation coefficient, and the asterisk

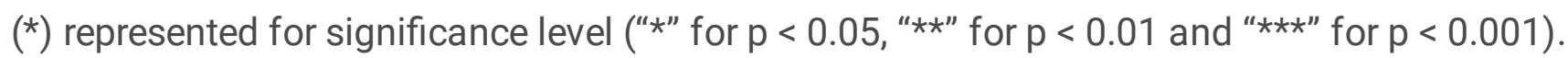


(a)

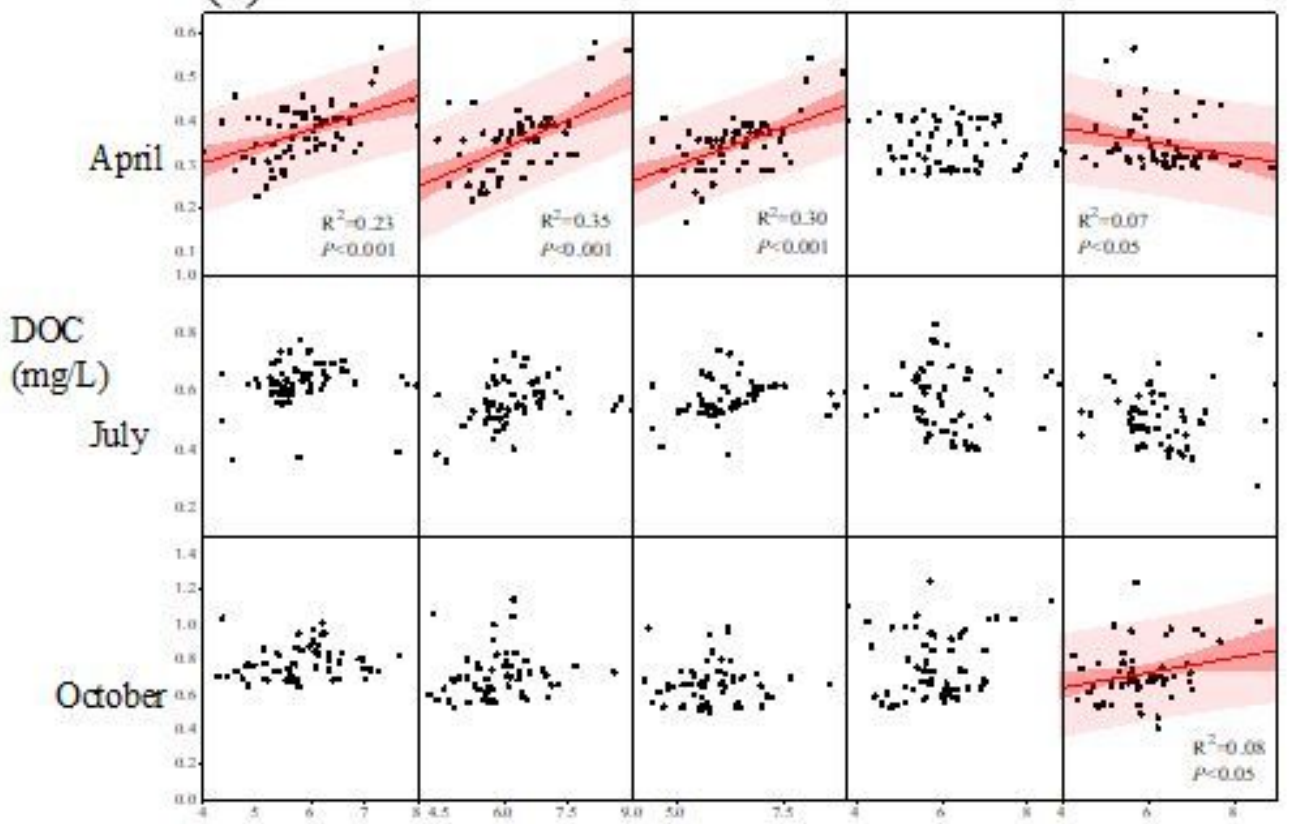

(b)

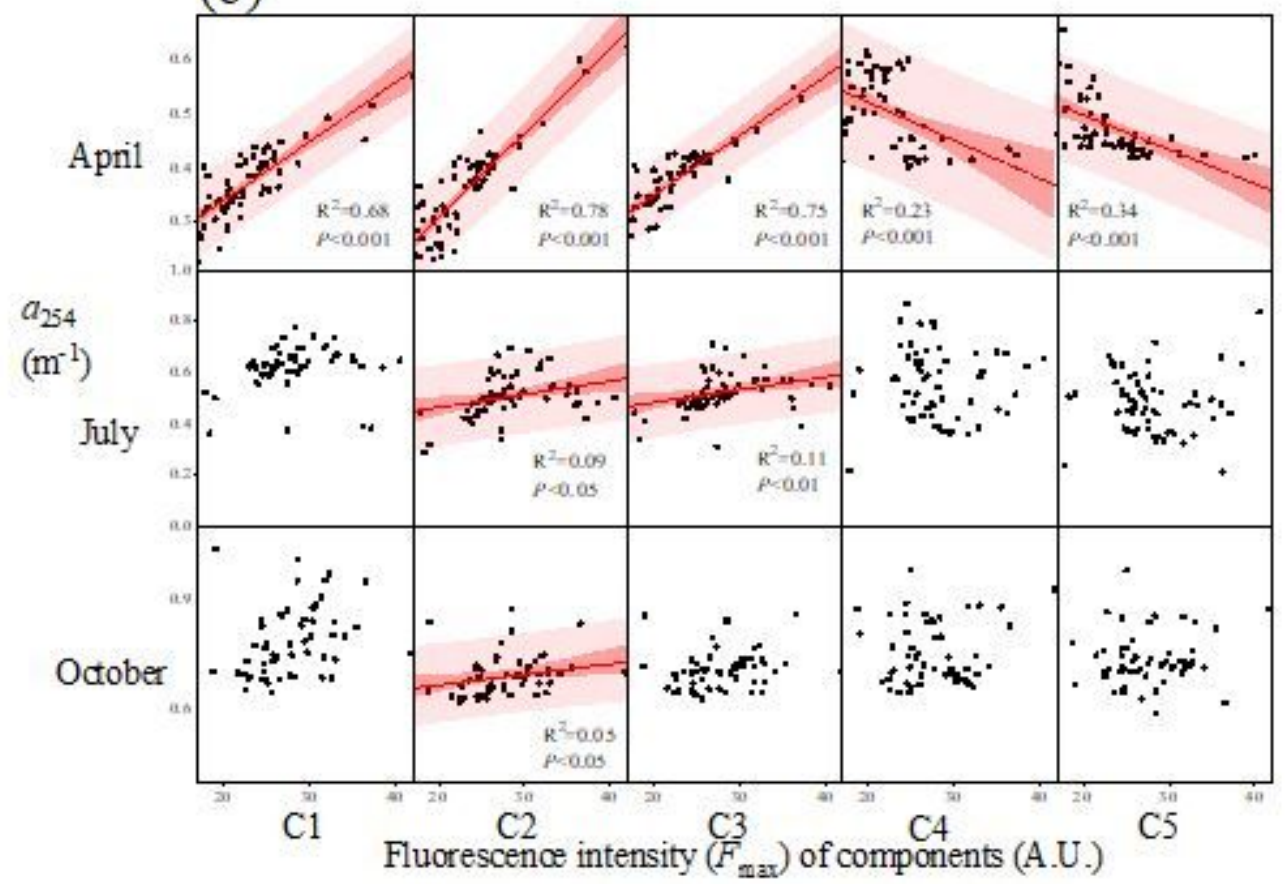

Figure 10

Relationships between fluorescence intensity of PARAFAC components C1-C5 and DOC in April, July and October (a). And Relationships between fluorescence intensity of PARAFAC components C1-C5 and a254 in April, July and October (b). 